\title{
Milk from Forage as Affected by Rumen Degradable Protein and Corn Grinding When Feeding Corn- and Alfalfa Silage-Based Diets
}

\author{
E. Charbonneau, ${ }^{\star}$ P. Y. Chouinard, ${ }^{\star}$ G. Allard,† H. Lapierre,‡ and D. Pellerin ${ }^{\star 1}$ \\ *Département des sciences animales, and \\ †Département de phytologie, Université Laval, Quebec, G1K 7P4 Canada \\ $\ddagger$ Agriculture and Agri-Food Canada, Lennoxville, Quebec, J1M 1 Z3 Canada
}

\section{ABSTRACT}

To increase the production of milk from forage (MF), a previous experiment with alfalfa silage showed the importance of a complementary combination of concentrates and forages offered. When corn silage is fed with alfalfa, increasing the rumen degradable protein (RDP) content in the diet should allow a better utilization of forage energy. To evaluate this hypothesis, 8 multiparous Holstein cows in early lactation were used in a replicated $4 \times 4$ Latin square design with 3 -wk periods. Diets were fed as total mixed rations and were formulated to provide similar levels of net energy for lactation and crude protein but differing in RDP. Corn and alfalfa silages were used. Treatments were: 1) cracked cornbased concentrate providing low RDP [level recommended by the NRC (2001); RDP $=11.1 \%$ of dry matter (DM)]; 2) cracked corn-based concentrate providing medium RDP ( $\mathrm{RDP}=12.8 \%$ of $\mathrm{DM}) ; 3$ ) cracked corn-based concentrate providing high $\mathrm{RDP}(\mathrm{RDP}=14.5 \%$ of $\mathrm{DM})$; and 4) ground corn-based concentrate providing high RDP ( $\mathrm{RDP}=13.6 \%$ of $\mathrm{DM})$. The first 3 treatments, using cracked corn, were compared on the basis of their RDP level. For these treatments, MF, calculated on a protein basis, decreased and the average of MF calculated on an energy basis and MF calculated on a protein basis tended to decrease as RDP increased. There was no difference for MF calculated on an energy basis between treatments. Increasing dietary RDP levels decreased the milk yield (from 32.8 to $30.7 \mathrm{~kg} / \mathrm{d}$ ) and milk protein yield (from 1,094 to $1,005 \mathrm{~g} / \mathrm{d}$ ) but not the milk fat yield. The milk urea $\mathrm{N}$ concentration increased as RDP increased. This suggests that there is no advantage of feeding RDP above the NRC recommendations when diets are based on corn and alfalfa silage. At high RDP levels (treatments 3 and 4), ground corn supported higher DM intake and yields of milk and protein than did cracked corn. Milk from forage, calculated on a protein basis, was higher and milk urea $\mathrm{N}$ decreased with

Received January 4, 2006.

Accepted September 6, 2006.

${ }^{1}$ Corresponding author: doris.pellerin@san.ulaval.ca ground corn. Even with corn silage in the diet, grinding corn grain proved to be beneficial to milk yield and MF production.

Key words: milk from forage, rumen degradable protein, corn grinding, dairy cow

\section{INTRODUCTION}

Milk from forage (MF) is a theoretical estimate of the amount of milk made from the forage portion of the diet; the estimated amount of milk allowed from concentrates is subtracted from the actual amount of milk produced (Charbonneau et al., 2003). This calculation assumes that the animal's maintenance requirements are being met through the forage portion of the diet (Charbonneau et al., 2003). Because MF estimates forage utilization, it can be used with any mixture of forage (Charbonneau et al., 2003). In Quebec, the annual operating profit for 2000 was, on average, CAN $\$ 15,995$ higher for dairy farms in the top $20 \%$ for MF production compared with farms in the bottom $20 \%$ for MF production (Charbonneau et al., 2003). Higher profits were related to lower production costs, especially for feed and health costs. In an alfalfa silage-based diet, it is possible to increase MF by improving the complementarity of the concentrates to the silage fed (Charbonneau et al., 2006). In that experiment, MF was elevated $3 \mathrm{~kg} / \mathrm{d}$ by increasing the rumen degradability of the carbohydrates in the concentrates: Ground corn or wheat starch induced more efficient use of $\mathrm{N}$ in the rumen compared with cracked corn.

We hypothesized, based on our previous work with alfalfa silage, that adequate selection of concentrates that complement alfalfa and corn silage would also increase MF production. Microbial proteins offer a good AA profile because their profile is similar to that of milk protein (Santos et al., 1998). It would be beneficial to increase their production with a complementary combination of forages and concentrates. To that extent, when corn silage is added to alfalfa silage in the diet, the increase in RDP should lead to better utilization of forage energy by maximizing microbial growth. Rumen degradable protein levels can be altered in many differ- 
ent ways. Soybean meal (SBM) is usually a good protein source with a moderate level of RDP (Santos et al., 1998). Chemical treatment of SBM can lower RDP levels substantially (Santos et al., 1998). An inexpensive and widely used means of increasing dietary RDP is to replace some SBM with urea. For diets that included corn silage, milk yield was not affected by using feeds with different RDP levels (Aldrich et al., 1993), or by feeding extruded vs. chemically treated SBM and SBM (Shabi et al., 1998; Casper et al., 1999; Dunlap et al., 2000), or by substituting SBM with urea (Casper et al., 1990).

Because MF indicates the effectiveness of forage utilization, our hypothesis was that, with an alfalfa- and corn silage-based diet, increasing the utilization of energy available from corn silage for microbial protein synthesis through an increase in RDP should lead to higher MF. Also, increasing the degradability of ruminal starch by grinding corn should permit better use of $\mathrm{RDP}$ and result in improved lactation performance. The objective of this study was to determine the effect on MF of using varying complementary combinations of concentrates in an alfalfa- and corn silage-based diet. No previous report has evaluated how complementation of the concentrate affects MF when the forage feed includes corn and alfalfa silage. The effects of increasing RDP levels by substituting chemically treated SBM for SBM or urea were tested. At high RDP levels, the effect on $\mathrm{MF}$ of using ground corn instead of cracked corn was also determined. Milk from forage, milk yield, and milk composition, along with blood components, were monitored and simulations were made using the NRC (2001) model to determine the effects of varying RDP levels and corn grinding.

\section{MATERIALS AND METHODS}

\section{Cows, Diets, and Experimental Design}

Eight multiparous Holstein cows in early lactation [94 \pm 15 DIM; $2.6 \pm 0.5$ parity; $609 \pm 53 \mathrm{~kg}$ of BW; 31.4 $\pm 7.5 \mathrm{~kg} / \mathrm{d}$ of milk yield (mean $\pm \mathrm{SD}$ )] were used in a replicated $4 \times 4$ Latin square design with 3 -wk periods. Cows were kept in a tie-stall facility. The first $2 \mathrm{wk}$ of each experimental period were allowed for cows to adapt to the diets, and the last week was used for data collection. All cows received the same forages, namely, alfalfa $(21.2 \%$ of DM) and corn (25.8\% of DM) silages (Table 1). Treatments were 1) cracked corn-based concentrate providing low RDP (level recommended by NRC, 2001; L-CC); 2) cracked corn-based concentrate providing medium RDP (M-CC); 3) cracked corn-based concentrate providing high RDP (H-CC); and 4) ground corn-based concentrate providing high RDP (H-GC; Table 1). Particle sizes of the cracked and ground corn
Table 1. Ingredients of experimental diets (\%, DM basis)

\begin{tabular}{|c|c|c|c|c|}
\hline \multirow[b]{2}{*}{ Ingredient } & \multicolumn{4}{|c|}{ Treatment $^{1}$} \\
\hline & $\mathrm{L}-\mathrm{CC}$ & $\mathrm{M}-\mathrm{CC}$ & $\mathrm{H}-\mathrm{CC}$ & $\mathrm{H}-\mathrm{GC}$ \\
\hline Alfalfa silage & 21.2 & 21.2 & 21.2 & 21.2 \\
\hline Corn silage & 25.8 & 25.8 & 25.8 & 25.8 \\
\hline Cracked corn & 39.2 & 39.2 & 45.4 & - \\
\hline Ground corn & - & - & - & 45.4 \\
\hline Treated soybean meal ${ }^{2}$ & 11.9 & - & - & - \\
\hline Soybean meal & - & 11.9 & 4.6 & 4.6 \\
\hline Urea & - & - & 1.2 & 1.2 \\
\hline Vitamins and minerals ${ }^{3}$ & 1.9 & 1.9 & 1.9 & 1.9 \\
\hline
\end{tabular}

${ }^{1} \mathrm{~L}-\mathrm{CC}=$ Cracked corn-based concentrate providing low RDP (requirements of NRC, 2001); M-CC = cracked corn-based concentrate providing medium RDP; $\mathrm{H}-\mathrm{CC}$ = cracked corn-based concentrate providing high $\mathrm{RDP}$; $\mathrm{H}-\mathrm{GC}$ = ground corn-based concentrate providing high RDP.

${ }^{2}$ Treated soybean meal: Top Soy is a chemically treated soybean meal to reduce protein degradability, a commercial product from Shur-Gain (Brossard, Québec, Canada).

${ }^{3}$ Mineral composition (DM basis): $\mathrm{Ca}=11.05 \% ; \mathrm{P}=7.36 \% ; \mathrm{Na}=$ $13.07 \% ; \mathrm{Cl}=20.52 \% ; \mathrm{Mg}=3.68 \% ; \mathrm{K}=0.18 \% ; \mathrm{S}=0.11 \% ; \mathrm{Cu}=801$ $\mathrm{mg} / \mathrm{kg} ; \mathrm{Mn}=2,670 \mathrm{mg} / \mathrm{kg} ; \mathrm{Zn}=4,009 \mathrm{mg} / \mathrm{kg} ; \mathrm{Fe}=4,235 \mathrm{mg} / \mathrm{kg} ; \mathrm{Co}=$ $29.46 \mathrm{mg} / \mathrm{kg} ; \mathrm{I}=80.09 \mathrm{mg} / \mathrm{kg} ; \mathrm{Se}=16.57 \mathrm{mg} / \mathrm{kg} ;$ vitamin $\mathrm{A}=360,000$ $\mathrm{UI} / \mathrm{kg}$; vitamin $\mathrm{D}=122,000 \mathrm{UI} / \mathrm{kg}$; vitamin $\mathrm{E}=1,215 \mathrm{UI} / \mathrm{kg}$.

were 3,400 and $700 \mu \mathrm{m}$, respectively. Diets were formulated based on NRC (2001) recommendations to provide similar levels of $\mathrm{NE}_{\mathrm{L}}(1.55 \mathrm{Mcal} / \mathrm{kg})$ and $\mathrm{CP}(18.1 \%$ of DM) but with different levels of RDP (Table 2). Diets were originally formulated to have RDP lower than, equal to, and higher than the NRC (2001) requirements. However, because the DMI was higher than estimated before experimentation with the NRC model (2001), our lower level of RDP (L-CC) already met NRC (2001) requirements.

Diets were fed as TMR, once daily in the morning, to provide $10 \%$ orts on an as-fed basis according to the previous day's intake. Before the experiment began, a 2-wk period was set aside for cows to adapt to the experimental feeds. Forage DM was determined twice weekly by drying samples in a forced-air oven at $65^{\circ} \mathrm{C}$ for $3 \mathrm{~d}$. Feed ingredients of TMR were adjusted each week to ensure stable proportions on a DM basis throughout the study. Cows were milked twice daily at 0700 and $1700 \mathrm{~h}$. The experimental protocol was approved by the Laval University Animal Care committee, and care of the cows followed the guidelines of the Canadian Council on Animal Care (1993).

\section{Measurements and Sampling}

During the last week of each period, BW of cows were recorded on 3 consecutive days, after the morning milking, to ensure that at least 2 of the weighings were similar. Individual feed intake was recorded daily. The TMR was sampled 4 times a week and orts were sam- 
Table 2. Chemical composition of forages and experimental diets

\begin{tabular}{|c|c|c|c|c|c|c|c|}
\hline \multirow[b]{2}{*}{ Chemical component } & \multicolumn{2}{|c|}{ Forage $^{1}$} & \multicolumn{5}{|c|}{ Treatment $^{2}$} \\
\hline & $\mathrm{AS}$ & CS & L-CC & $\mathrm{M}-\mathrm{CC}$ & $\mathrm{H}-\mathrm{CC}$ & $\mathrm{H}-\mathrm{GC}$ & $\mathrm{SE}$ \\
\hline $\mathrm{DM}, \%$ & 35.2 & 31.2 & 46.7 & 46.9 & 46.4 & 47.1 & 0.25 \\
\hline $\mathrm{NE}_{\mathrm{L}},{ }^{3} \mathrm{Mcal} / \mathrm{kg}$ & - & - & 1.54 & 1.54 & 1.56 & 1.54 & - \\
\hline $\mathrm{ADF}, \%$ of $\mathrm{DM}$ & 37.2 & 31.9 & 19.2 & 19.1 & 18.6 & 17.4 & 0.26 \\
\hline $\mathrm{NDF}, \%$ of $\mathrm{DM}$ & 41.7 & 49.7 & 30.9 & 30.2 & 30.2 & 28.5 & 0.36 \\
\hline $\mathrm{CP}, \%$ of $\mathrm{DM}$ & 21.6 & 10.0 & 17.9 & 18.0 & 18.8 & 17.7 & 0.11 \\
\hline NPN, \% of DM & - & - & 5.7 & 7.4 & 9.7 & 9.6 & - \\
\hline Soluble protein, $\%$ of DM & 15.2 & 4.9 & 5.8 & 7.5 & 10.1 & 9.8 & - \\
\hline NDIP, $4 \%$ of DM & 1.6 & 1.9 & 1.2 & 1.3 & 1.2 & 1.1 & - \\
\hline $\mathrm{ADIP}, 5 \%$ of $\mathrm{DM}$ & 0.4 & 1.1 & 1.1 & 1.0 & 1.0 & 0.8 & - \\
\hline $\mathrm{RDP}^{6}{ }^{6} \%$ of DM & - & - & 11.1 & 12.8 & 14.5 & 13.6 & - \\
\hline $\mathrm{NFC},{ }^{3} \% \mathrm{DM}$ & - & - & 42.3 & 43.6 & 42.5 & 45.8 & 0.37 \\
\hline
\end{tabular}

${ }^{1} \mathrm{AS}=$ Alfalfa silage; $\mathrm{CS}=$ corn silage.

${ }^{2} \mathrm{~L}-\mathrm{CC}=$ Cracked corn-based concentrate providing low RDP (NRC, 2001, requirements); M-CC = cracked corn-based concentrate providing medium RDP; H-CC = cracked corn-based concentrate providing high RDP; H-GC = ground corn-based concentrate providing high RDP.

${ }^{3}$ Estimated for each treatment using the average for intake, cow characteristics, and available diet and nutrient information of the treatment with NRC recommendations (2001).

${ }^{4} \mathrm{NDIP}=$ Neutral detergent insoluble protein.

${ }^{5} \mathrm{ADIP}=$ Acid detergent insoluble protein.

${ }^{6}$ Estimated for each treatment using the average for intake, cow characteristics, and available diet and nutrient information of the treatment with NRC recommendations (2001); results from the NRC (2001) simulation using table values for feeds were confirmed using NPN, soluble protein, NDIP, and ADIP.

pled each following day. Subsamples were pooled by treatments per period and kept at $-20^{\circ} \mathrm{C}$ for chemical analysis. Milk yield was recorded for the last 8 consecutive milkings, and milk was sampled for these 8 milkings for further composition analyses using 2-bromo-2nitropropan-1,3-diol as a preservative.

Caudal vein blood samples were collected twice by venipuncture in EDTA tubes on d 20 of each period at $-1 \mathrm{~h}$ before feeding $(0900 \mathrm{~h})$ and $5 \mathrm{~h}$ postfeeding (1500 h). Samples were cooled on ice until plasma was harvested after centrifugation at $1,268 \times g$ for $15 \mathrm{~min}$ at $4^{\circ} \mathrm{C}$. Plasma was kept at $-20^{\circ} \mathrm{C}$ until further analysis of urea $\mathrm{N}$, glucose, and NEFA.

\section{Chemical Analysis}

Total mixed ration and ort samples were freeze-dried. Once dried, they were ground in a Wiley mill (Arthur H. Thomas Co., Philadelphia, PA) through a 2-mm screen, and then in a Cyclotec 1093 sample mill (Tecator Inc., Höganas, Sweden) through a 1-mm screen. Samples were analyzed for ADF and NDF using the Ankom immersion method (Ankom ${ }^{200}$ fiber analyzer, Ankom, Fairport, NY; Ankom, 1999a,b), and for CP following the Kjeldahl procedure (Kjel-Foss Automatic 16210, A/ SN; Foss Electric, Hillerød, Denmark; AOAC, 1990). Total mixed rations were pooled by treatment and analyzed by Agribrands Purina Canada Central Laboratory (Strathroy, Ontario, Canada) for NPN using a Foss Te- cator System 6 (Foss Electric), soluble protein using a phosphate buffer and a Foss 6500 (Foss Electric), and neutral detergent insoluble protein as well as acid detergent insoluble protein using an Ankom ${ }^{200}$ fiber analyzer. The DMI and nutrient intake were adjusted for orts. Intakes of $\mathrm{ADF}, \mathrm{NDF}$, and $\mathrm{CP}$ were calculated by subtracting the quantity of each component in orts from its quantity in TMR.

Milk samples from each individual milking were analyzed by the Program d'analyze des troupeaux laitiers du Québec (Ste-Anne-de-Bellevue, Québec) for fat, protein, lactose, and MUN concentrations. Fat and protein concentrations were determined using a Foss MilkoScan 4000 (Foss Electric) combined with a Bentley 2000 (Bentley Instruments, Chaska, MN). Lactose and MUN were measured with a Foss MilkoScan 4000 (Foss Electric). Weighted averages for milk yield per milking were then calculated for each cow in each period.

Urea concentrations in plasma were determined using a colorimetric method (Huntington, 1984) with a Technicon analyzer (Technicon Autoanalyzer II; Technicon Instruments Corporation, Tarrytown, NY). Glucose concentrations were determined with colorimetric kits from Boehringer Mannheim (Dorval, Quebec, Canada). An enzymatic procedure with a kit (\#990-75401; Wako Chemicals, Dallas, TX) was used to determine NEFA concentrations, as described by McCutcheon and Bauman (1986). Blood parameter analyses were performed on prefeeding and postfeeding samples to com- 
pare the effects of times before and after feeding on the results. Because no major differences were observed between prefeeding and postfeeding values, for the purposes of this study the average of these 2 analyses was used.

One cow developed a respiratory problem (infectious bovine rhinotracheitis) during the last $2 \mathrm{~d}$ of the last experimental period. The cow stopped eating; therefore, only data (DMI, TMR, and orts sampling results) for the first $2 \mathrm{~d}$ of the collection week were included for this cow. Milk yields and milk samples were recorded and collected for the first 4 milkings only, and no blood samples were analyzed for this cow in the last period.

\section{Calculations}

The NRC (2001) model was used in the evaluation and interpretation of daily intake of RDP, RUP, MP, MP-bacterial, MP-RUP, and $\mathrm{NE}_{\mathrm{L}}$. These parameters were estimated for each cow individually using actual intake, cow characteristics, and diet of each cow for each period.

Milk from forage on an energy basis ( $\left.\mathbf{M F}_{\text {energy }}\right), \mathbf{M F}$ on a protein basis ( $\left.\mathbf{M F}_{\text {protein }}\right)$, the average $\left(\mathbf{M F}_{\text {average }}\right)$ of $\mathrm{MF}_{\text {energy }}$ and $\mathrm{MF}_{\text {protein }}, \mathrm{ECM}$, and protein-corrected milk were calculated for each cow at each period using the equations of Charbonneau et al. (2006).

Allowable milk from forage (AMF) estimates the potential of forage for milk production. The AMF was calculated both on an energy basis $\left(\mathbf{A M F}_{\text {energy }}\right)$ and on a protein basis $(\mathbf{A M F}$ protein $)$. Average $\mathrm{AMF}$ is the average of $\mathrm{AMF}_{\text {energy }}$ and $\mathrm{AMF}_{\text {protein }}$. These values were calculated using the equations of Charbonneau et al. (2006).

Because the maintenance requirements of cows are attributed to forage in both $\mathrm{MF}$ and $\mathrm{AMF}$, it is possible to compare these 2 values. The difference between AMF and MF was calculated for energy, protein, and the average of both. The results represent the gap between the potential of forage for milk production (AMF) and the estimation of how the forages were used for milk production (MF). Small differences indicate better utilization of the forages.

\section{Statistical Analysis}

Body weight, DMI, blood metabolites, milk yield and composition, and MF were averaged for each cow within period. Data were analyzed with ANOVA using the GLM procedure of SAS 8.2 (SAS Institute, 2001) for a replicated $4 \times 4$ Latin square design. Blood metabolites were statistically analyzed using the mixed model procedure of SAS because there was a missing value for blood metabolites. Cows were defined as random effects, and Akaike's information criterion was used to select the best covariance structure from among compound symmetry, first-order autoregressive, and unstructured. For all response variables, contrasts were used to test treatment effects. Comparisons were established before the experimentation. Linear and quadratic contrasts were applied to increments in the percentage of RDP requirements relative to NRC (2001) recommendations. Increments were proportional among low-, medium-, and high-RDP treatments. Two degrees of freedom were used to evaluate the impact of increasing RDP. The remaining degree of freedom was used to compare cracked corn and ground corn treatments in diets high in RDP. Contrasts among treatments were interpreted only when $P<0.10$. They were declared significant for $P<0.05$, whereas trends were mentioned for $P$-values between 0.05 and 0.10 .

\section{RESULTS}

The analysis according to the NRC (2001) model determined diets to be isoenergetic despite slight variations in nutrient composition (Table 2). Some differences were found in fiber content, especially between the H-GC diet and the other treatments (Table 2). Most of these variations could be attributed to the higher NFC of H-GC, likely because ground corn is higher in NFC than is cracked corn. Although both types of corn were purchased from the same feed mill at the same time, the sources of cracked and ground corn might not have been the same. For the simulation with the NRC (2001) model, all the variation between $\mathrm{H}-\mathrm{CC}$ and H-GC was attributed to corn, because the other ingredients of the diet were exactly the same and in the same proportions for both treatments.

The DMI was not affected by increasing the RDP (Table 3). The combination of numerically lower DMI and lower ADF and NDF in the diets, as well as small variations from cows sorting the TMR between treatments, resulted in decreased $\mathrm{ADF}$ and NDF intakes with the increase in RDP (Table 3). Crude protein intake was not affected by treatment. With the increase in RDP, there was an increase in the estimated RDP supplied and a decrease in the estimated RUP supplied (Table 3). The estimated MP supply decreased as a function of decreased RUP; MP-bacterial was not affected by the RDP level. The estimated $\mathrm{NE}_{\mathrm{L}}$ supply was not affected by the RDP level (Table 3). Adding ground corn instead of cracked corn at high levels of RDP resulted in higher DMI as well as higher DMI as a percentage of BW but did not affect ADF, NDF, or CP intakes (Table 3). This is because of lower concentrations of these components in the H-CG diet. The pre- 
Table 3. Daily intakes of DM, fiber, and CP, and NRC prediction for RDP and RUP, MP, and ME in cows fed diets varying in RDP content and supplemented with cracked or ground corn

\begin{tabular}{|c|c|c|c|c|c|c|c|c|}
\hline \multirow[b]{2}{*}{ Item } & \multicolumn{4}{|c|}{ Treatment $^{1}$} & \multirow[b]{2}{*}{ SEM } & \multicolumn{3}{|c|}{$P,{ }^{2}$ contrasts } \\
\hline & L-CC & $\mathrm{M}-\mathrm{CC}$ & $\mathrm{H}-\mathrm{CC}$ & $\mathrm{H}-\mathrm{GC}$ & & Lin. & Quad. & $\mathrm{CC}$ vs. GC \\
\hline DMI, kg/d & 24.8 & 24.3 & 23.9 & 25.7 & 0.43 & 0.13 & 0.92 & $<0.01$ \\
\hline DMI, $\%$ of BW & 4.1 & 4.0 & 4.0 & 4.3 & 0.07 & 0.25 & 0.95 & 0.01 \\
\hline $\mathrm{ADF}, \mathrm{kg} / \mathrm{d}$ & 4.8 & 4.6 & 4.4 & 4.5 & 0.09 & 0.03 & 0.83 & 0.88 \\
\hline $\mathrm{NDF}, \mathrm{kg} / \mathrm{d}$ & 7.7 & 7.3 & 7.3 & 7.2 & 0.14 & 0.03 & 0.44 & 0.57 \\
\hline $\mathrm{CP}, \mathrm{kg} / \mathrm{d}$ & 4.5 & 4.4 & 4.5 & 4.6 & 0.09 & 0.74 & 0.27 & 0.75 \\
\hline $\mathrm{RDP}^{3} \mathrm{~g} / \mathrm{d}$ & 2,767 & 3,103 & 3,450 & 3,384 & 56.9 & $<0.001$ & 0.94 & 0.42 \\
\hline $\mathrm{RUP}^{3}, \mathrm{~g} / \mathrm{d}$ & 1,684 & 1,264 & 1,037 & 993 & 34.9 & $<0.001$ & 0.04 & 0.39 \\
\hline $\mathrm{MP},{ }^{3} \mathrm{~g} / \mathrm{d}$ & 2,775 & 2,481 & 2,242 & 2,264 & 49.1 & $<0.001$ & 0.66 & 0.76 \\
\hline MP-bacterial, ${ }^{3} \mathrm{~g} / \mathrm{d}$ & 1,306 & 1,277 & 1,259 & 1,313 & 20.1 & 0.12 & 0.83 & 0.07 \\
\hline MP-RUP ${ }^{3}$ g/d & 1,352 & 1,091 & 871 & 834 & 28.2 & $<0.001$ & 0.55 & 0.37 \\
\hline $\mathrm{NE}_{\mathrm{L}},{ }^{3} \mathrm{Mcal} / \mathrm{d}$ & 38.0 & 37.3 & 36.9 & 38.3 & 0.55 & 0.16 & 0.74 & 0.09 \\
\hline
\end{tabular}

${ }^{1} \mathrm{~L}-\mathrm{CC}=$ Cracked corn-based concentrate providing low RDP (requirements of NRC, 2001); M-CC = cracked corn-based concentrate providing medium RDP; H-CC = cracked corn-based concentrate providing high RDP; H-GC = ground corn-based concentrate providing high RDP.

${ }^{2}$ Lin. and Quad. $=P$ for linear and quadratic effects of the proportion of RDP relative to NRC (2001) requirements, within $\mathrm{CC}$ treatments.

${ }^{3}$ Estimated for each cow individually using actual intake, characteristics, and diet of each cow for each period with the NRC (2001) model.

dicted $\mathrm{NE}_{\mathrm{L}}$ supply and MP-bacterial tended to increase with the H-GC diet.

No differences in BW and BW change were observed as RDP increased, nor were differences found between cracked and ground corn (Table 4). However, these results need to be interpreted cautiously because the 3wk periods used in the trial may not adequately reflect true changes in BW gain or loss; they could be bias attributable to differences in ruminal fill.

Milk yield and protein-corrected milk decreased linearly with increasing RDP (Table 5). Milk fat content and yield were not affected by RDP levels. Protein and lactose yields decreased linearly with increasing RDP (Table 5). The milk protein concentration followed a quadratic response, with the protein concentration being higher in the M-CC treatment. Increasing the RDP resulted in higher MUN (Table 5). The efficiency of energy utilization was not affected by treatment, but the efficiency of nitrogen utilization decreased with increasing RDP (Table 5).
With high RDP, using ground corn instead of cracked corn resulted in higher milk yields (Table 5). Fat production did not differ significantly with the H-CC and H-GC treatments, but the fat content was lower with the H-GC treatment (Table 5). Protein production was greater with H-GC, and despite the increase in milk yield, the milk protein concentration also increased compared with H-CC. Milk lactose contents were similar for H-CC and H-GC, but milk lactose yield increased with the H-GC treatment (Table 5). The MUN concentration was lower for H-GC than for H-CC (Table 5). Energy efficiency did not change, but $\mathrm{N}$ utilization efficiency increased with $\mathrm{H}-\mathrm{GC}$ in comparison with $\mathrm{H}-\mathrm{CC}$ (Table 5).

Plasma concentrations of NEFA tended to increase as the RDP increased (Table 6). Plasma glucose tended to follow a quadratic response because of a lower glucose concentration for M-CC. The plasma urea-N concentration increased linearly as the RDP increased (Table 6). Nonesterified fatty acid concentrations were similar for

Table 4. Final BW and average BW change in cows fed diets varying in RDP content, and supplemented with cracked or ground corn

\begin{tabular}{|c|c|c|c|c|c|c|c|c|}
\hline \multirow[b]{2}{*}{ Item } & \multicolumn{4}{|c|}{ Treatment $^{1}$} & \multirow[b]{2}{*}{ SEM } & \multicolumn{3}{|c|}{$P,^{2}$ contrasts } \\
\hline & $\mathrm{L}-\mathrm{CC}$ & $\mathrm{M}-\mathrm{CC}$ & $\mathrm{H}-\mathrm{CC}$ & H-GC & & Lin. & Quad. & $\mathrm{CC}$ vs. GC \\
\hline BW, kg & 613 & 609 & 605 & 608 & 2.8 & 0.06 & 0.96 & 0.41 \\
\hline BW change, kg/d & 0.81 & 0.68 & 0.21 & 0.51 & 0.20 & 0.05 & 0.52 & 0.31 \\
\hline
\end{tabular}

${ }^{1} \mathrm{~L}-\mathrm{CC}=$ Cracked corn-based concentrate providing low RDP (requirements of NRC, 2001); M-CC = cracked corn-based concentrate providing medium RDP; H-CC = cracked corn-based concentrate providing high RDP; H-GC = ground corn-based concentrate providing high RDP.

${ }^{2} \mathrm{Lin}$. and Quad. $=P$ for linear and quadratic effects of RDP proportion relative to NRC (2001) requirements, within CC treatments. 
Table 5. Milk yield and composition in cows fed diets varying in RDP content and supplemented with cracked or ground corn

\begin{tabular}{|c|c|c|c|c|c|c|c|c|}
\hline \multirow[b]{2}{*}{ Item } & \multicolumn{4}{|c|}{ Treatment ${ }^{1}$} & \multirow[b]{2}{*}{ SEM } & \multicolumn{3}{|c|}{$P,{ }^{2}$ contrasts } \\
\hline & L-CC & $\mathrm{M}-\mathrm{CC}$ & $\mathrm{H}-\mathrm{CC}$ & $\mathrm{H}-\mathrm{GC}$ & & Lin. & Quad. & $\mathrm{CC}$ vs. GC \\
\hline \multicolumn{9}{|l|}{ Milk yield } \\
\hline Actual, kg/d & 32.8 & 31.4 & 30.7 & 33.4 & 0.60 & 0.02 & 0.69 & $<0.01$ \\
\hline Energy-corrected ${ }^{3} \mathrm{~kg} / \mathrm{d}$ & 31.5 & 31.2 & 30.0 & 31.0 & 0.62 & 0.10 & 0.61 & 0.26 \\
\hline Protein-corrected, ${ }^{4} \mathrm{~kg} / \mathrm{d}$ & 32.1 & 31.3 & 29.6 & 33.4 & 0.61 & $<0.01$ & 0.56 & $<0.001$ \\
\hline \multicolumn{9}{|l|}{ Fat } \\
\hline Concentration, \% & 3.72 & 3.95 & 3.91 & 3.37 & 0.08 & 0.12 & 0.19 & $<0.001$ \\
\hline Yield, g/d & 1,224 & 1,234 & 1,197 & 1,146 & 32.7 & 0.56 & 0.57 & 0.29 \\
\hline \multicolumn{9}{|l|}{ Protein } \\
\hline Concentration, \% & 3.34 & 3.40 & 3.31 & 3.41 & 0.02 & 0.28 & $<0.01$ & $<0.01$ \\
\hline Yield, g/d & 1,094 & 1,061 & 1,005 & 1,133 & 21.0 & $<0.01$ & 0.66 & $<0.001$ \\
\hline \multicolumn{9}{|l|}{ Lactose } \\
\hline Concentration, $\%$ & 4.60 & 4.57 & 4.62 & 4.63 & 0.02 & 0.46 & 0.09 & 0.71 \\
\hline $\begin{array}{l}\text { Yield, g/d } \\
\text { MUN }\end{array}$ & 1,508 & 1,435 & 1,416 & 1,543 & 31.1 & 0.05 & 0.49 & $<0.01$ \\
\hline $\begin{array}{l}\text { Concentration, mg/dL } \\
\text { Efficiency }\end{array}$ & 13.3 & 14.9 & 16.6 & 13.3 & 0.33 & $<0.001$ & 0.95 & $<0.001$ \\
\hline $\mathrm{NE}_{\mathrm{L} \text { milk }} / \mathrm{NE}_{\mathrm{L} \text { ingested, }},{ }^{5} \%$ & 61.75 & 62.13 & 60.63 & 59.88 & 0.01 & 0.48 & 0.49 & 0.63 \\
\hline $\mathrm{N}_{\text {milk }} / \mathrm{N}_{\text {ingested }}, 6 \%$ & 23.92 & 23.63 & 21.85 & 24.25 & 0.45 & $<0.01$ & 0.19 & $<0.01$ \\
\hline
\end{tabular}

${ }^{1} \mathrm{~L}-\mathrm{CC}=$ Cracked corn-based concentrate providing low RDP (requirements of NRC, 2001); M-CC = cracked corn-based concentrate providing medium RDP; H-CC = cracked corn-based concentrate providing high RDP; H-GC = ground corn-based concentrate providing high RDP.

${ }^{2}$ Lin. and Quad. $=P$ for linear and quadratic effects of RDP proportions relative to NRC (2001) requirements, within CC treatments.

${ }^{3}$ Energy-corrected milk $(4 \%$ fat, $3.4 \%$ protein $)=$ Milk $\times(0.124 \%$ fat $+0.073 \% \mathrm{CP}+0.256)$

${ }^{4}$ Protein-corrected milk $(3.4 \%$ protein $)=$ Milk $\times 0.296 \% \mathrm{CP}$.

${ }^{5} \mathrm{NE}_{\mathrm{L} \text { milk }} / \mathrm{NE}_{\mathrm{L} \text { ingested }}=[\mathrm{ECM}(\mathrm{kg}$ of milk $) \times 0.75 \mathrm{Mcal} / \mathrm{kg}$ of milk $] / \mathrm{NE}_{\mathrm{L} \text { ingested }}(\mathrm{Mcal})$ estimated with NRC (2001) recommendations.

${ }^{6} \mathrm{~N}_{\text {milk }} / \mathrm{N}_{\text {ingested }}=[$ Milk protein yield $(\mathrm{kg}) / 6.38(\mathrm{~kg}$ of milk protein $/ \mathrm{kg}$ of $\mathrm{N})] /[\mathrm{CP}$ intake $(\mathrm{kg}) / 6.25(\mathrm{~kg}$ of protein $/ \mathrm{kg}$ of $\mathrm{N})$ ].

cows fed H-GC and H-CC (Table 6). The H-GC treatment resulted in higher plasma glucose levels, but plasma urea-N levels were lower compared with the $\mathrm{H}$ $\mathrm{CC}$ treatment.

Increasing the RDP mainly affected $\mathrm{MF}_{\text {protein }}$; more $\mathrm{MF}_{\text {protein }}$ was obtained at lower RDP levels (Table 7). Even when $\mathrm{MF}_{\text {protein }}$ was significantly different with increasing RDP, average milk from forage $\left(\mathrm{MF}_{\text {average }}\right)$ did not vary significantly. This result is due to the lack of variation in $\mathrm{MF}_{\text {energy. }}$. Better forage complementation was achieved with lower RDP levels. Using ground corn instead of cracked corn in diets high in RDP increased $\mathrm{MF}_{\text {protein }}$ (Table 7). For all treatments, the difference [(AMF - MF) $\left.)_{\text {average }}\right]$ was, on average, $12.5 \mathrm{~kg} / \mathrm{d}$ (Table 7). For all treatments, $\mathrm{MF}_{\text {energy }}$ was an average of 8.4 $\mathrm{kg} / \mathrm{d}$ lower than $\mathrm{AMF}_{\text {energy }}$, and $\mathrm{MF}_{\text {protein }}$ was $16.6 \mathrm{~kg} / \mathrm{d}$ lower than $\mathrm{AMF}_{\text {protein }}$ (Table 7). Forage utilization was not increased by any treatment because the differences between AMF and MF did not vary significantly among treatments (Table 7).

Table 6. Plasma metabolites in cows fed diets varying in RDP content and supplemented with cracked or ground corn

\begin{tabular}{|c|c|c|c|c|c|c|c|c|}
\hline \multirow[b]{2}{*}{ Item } & \multicolumn{4}{|c|}{ Treatment $^{1}$} & \multirow[b]{2}{*}{ SEM } & \multicolumn{3}{|c|}{$P,^{2}$ contrasts } \\
\hline & L-CC & M-CC & $\mathrm{H}-\mathrm{CC}$ & $\mathrm{H}-\mathrm{GC}$ & & Lin. & Quad. & CC vs. GC \\
\hline NEFA, $\mu \mathrm{Eq} / \mathrm{L}$ & 113.9 & 107.5 & 137.7 & 117.3 & 9.35 & 0.07 & 0.07 & 0.11 \\
\hline Glucose, $\mathrm{m} M$ & 3.1 & 3.0 & 3.1 & 3.3 & 0.10 & 0.52 & 0.06 & 0.02 \\
\hline $\mathrm{PUN},{ }^{3} \mathrm{~m} M$ & 10.2 & 11.7 & 13.6 & 11.3 & 0.52 & $<0.001$ & 0.57 & $<0.001$ \\
\hline
\end{tabular}

${ }^{1} \mathrm{~L}-\mathrm{CC}=$ Cracked corn-based concentrate providing low RDP (requirements of NRC, 2001); M-CC = cracked corn-based concentrate providing medium RDP; H-CC = cracked corn-based concentrate providing high RDP; H-GC = ground corn-based concentrate providing high RDP.

${ }^{2}$ Lin. and Quad. $=P$ for linear and quadratic effects of RDP proportions relative to NRC $(2001)$ requirements, within CC treatments.

${ }^{3} \mathrm{PUN}=$ Plasma urea nitrogen. 
Table 7. Milk from forage (MF) and allowable milk from forage (AMF) in cows fed diets varying in RDP content and supplemented with cracked or ground corn

\begin{tabular}{|c|c|c|c|c|c|c|c|c|}
\hline \multirow[b]{2}{*}{ Item $^{1}$} & \multicolumn{4}{|c|}{ Treatment $^{2}$} & \multirow[b]{2}{*}{ SEM } & \multicolumn{3}{|c|}{$P,,^{3}$ contrasts } \\
\hline & L-CC & $\mathrm{M}-\mathrm{CC}$ & $\mathrm{H}-\mathrm{CC}$ & H-GC & & Lin. & Quad. & CC vs. GC \\
\hline $\mathrm{MF}_{\text {energy }}, \mathrm{kg} / \mathrm{d}$ & 1.9 & 2.8 & -0.8 & -1.4 & 1.55 & 0.24 & 0.25 & 0.79 \\
\hline $\mathrm{MF}_{\text {protein }}, \mathrm{kg} / \mathrm{d}$ & 4.2 & 4.0 & 2.3 & 4.2 & 0.61 & 0.03 & 0.35 & 0.03 \\
\hline $\mathrm{MF}_{\text {average }}, \mathrm{kg} / \mathrm{d}$ & 3.1 & 3.4 & 0.7 & 1.4 & 0.97 & 0.11 & 0.23 & 0.62 \\
\hline$(\mathrm{AMF}-\mathrm{MF})_{\text {energy }}, \mathrm{kg} / \mathrm{d}$ & 7.2 & 5.7 & 9.2 & 11.3 & 1.68 & 0.43 & 0.27 & 0.38 \\
\hline$(\mathrm{AMF}-\mathrm{MF})_{\text {protein }}, \mathrm{kg} / \mathrm{d}$ & 16.2 & 15.8 & 17.1 & 17.2 & 0.92 & 0.47 & 0.49 & 0.96 \\
\hline$(\mathrm{AMF}-\mathrm{MF})_{\text {average }}, \mathrm{kg} / \mathrm{d}$ & 11.7 & 10.8 & 13.1 & 14.2 & 1.18 & 0.40 & 0.29 & 0.52 \\
\hline
\end{tabular}

${ }^{1} \mathrm{MF}_{\text {energy }}=$ Milk from forage on an energy basis; $\mathrm{MF}_{\text {protein }}=$ milk from forage on a protein basis; $\mathrm{MF}_{\text {average }}=$ average milk from forage; $(\mathrm{AMF}-\mathrm{MF})_{\text {energy }}=$ allowable milk from forage energy minus milk from forage on an energy basis; $(\mathrm{AMF}-\mathrm{MF})_{\text {protein }}=$ allowable milk from forage protein minus milk from forage on a protein basis; $(\mathrm{AMF}-\mathrm{MF})_{\text {average }}=$ average allowable milk from forage minus average milk from forage.

${ }^{2} \mathrm{~L}-\mathrm{CC}=$ Cracked corn-based concentrate providing low RDP (requirements of NRC, 2001); M-CC = cracked corn-based concentrate providing medium RDP; H-CC = cracked corn-based concentrate providing high $\mathrm{RDP} ; \mathrm{H}-\mathrm{GC}=$ ground corn-based concentrate providing high RDP.

${ }^{3} \mathrm{Lin}$. and Quad. = $P$ for linear and quadratic effects of the proportion of RDP relative to NRC (2001) requirements, within $\mathrm{CC}$ treatments.

\section{DISCUSSION}

\section{Effects of Increasing RDP with Cracked Corn Concentrates}

Increasing the RDP levels drastically decreased the estimated MP supply. The expectations were that high RDP levels would facilitate better energy use from the corn silage, and this in turn would deliver more microbial protein and thus compensate for the decrease in RUP. In 27 studies using SBM (Santos et al., 1998), microbial $\mathrm{N}$ flow to the duodenum decreased with an increased RUP. In contrast, a postexperiment simulation from our data showed a numerical decrease in estimated MP-bacterial with the increase in RDP (Table 3). This decrease led to a decrease in the estimated MP supply mainly related to a decrease in RUP (Table 3). In the present experiment, lower performances with increasing RDP for milk yield, protein-corrected milk (3.4\% protein), milk protein, and lactose productions (Table 5), along with changes in $\mathrm{MF}_{\text {protein }}$ and $\mathrm{MF}_{\text {average }}$ (Table 7), could be explained in part by the lower MP supply (Table 3). The estimated MP balance (NRC, 2001) for the diets using cracked corn averaged 392 , 143 , and $6 \mathrm{~g} / \mathrm{d}$, from the lowest to the highest RDP levels, respectively. The close-to-zero balance achieved at the high RDP level may indicate that the cows receiving this diet were limited by the MP supply in their milk protein output. The NRC (2001) model was used to estimate DMI prior to the start of the experiment. This estimation was lower than reality by an average of $2 \mathrm{~kg} / \mathrm{d}$. This low estimated value could explain the high level of MP. Because the cows ate more than anticipated, they received $15 \%$ more than the preexperimental estimated RDP per treatment, and treatments were at 100,115 , and $130 \%$ of the NRC requirement instead of 85,100 , and $115 \%$. The underestimation of DMI also resulted in low MF for all treatments. The concentration of nutrients in the diets exceeded nutritional requirements, and this resulted in lower MF (Table 7).

In this experiment, milk yield, $\mathrm{MF}_{\text {protein }}$, and $\mathrm{MF}_{\text {average }}$ were highest with the lowest dietary RDP. Increasing the RDP from concentrates was not necessary with a mixture of corn and alfalfa silages, and led to a decrease in the efficiency of $\mathrm{N}$ utilization (Table 5). Dhiman and Satter (1997) reported that feeding a mixture of corn and alfalfa silage was beneficial for $\mathrm{N}$ utilization as compared with an alfalfa silage-based diet. Feeding alfalfa silage had already provided sufficient RDP for use with the corn silage. The decrease in MP available for milk production with the increase in RDP had the greatest effect on $\mathrm{MF}_{\text {protein. }}$. Other studies evaluating different RDP levels did not record any variation in milk yield (Aldrich et al., 1993; Casper et al., 1999; Dunlap et al., 2000). Only 6 comparisons out of 29 in which SBM was replaced by heated or chemically treated SBM resulted in increased milk yield (Santos et al., 1998).

The energy cost of detoxifying the absorbed ammonia generated by high RDP into urea could also be a contributing factor in the lower performances associated with increased dietary RDP. Higher MUN (Table 5) and plasma urea-N (Table 6) indicate greater urea production with higher RDP levels. Some studies (Oldham, 1984; Garcia-Bojalil et al., 1998) have indicated that the energy balance of cows is affected when urea is synthesized and eliminated. In this study, cows receiving the H-CC diet would have been most affected because the RDP level was the highest in this treatment. Martin and Blaxter (1965) estimate the energy cost for urea synthesis at $88.4 \mathrm{kcal} / \mathrm{mol}$ of urea synthesized. As a rough estimate, ammonia absorption can be defined 
as digested CP intake minus MP. This would mean that nearly $300 \mathrm{mmol} / \mathrm{h}$ of extra ammonia is absorbed with H-CC compared with L-CC; the extra energy cost of detoxifying ammonia for the H-CC treatment could be estimated at $0.85 \mathrm{Mcal}$, including a $30 \%$ recycling of the absorbed ammonia (Martin and Blaxter, 1965). The latter energy cost added to the $1.1 \mathrm{Mcal}$ difference in energy ingestion resulted in a nearly 2 -Mcal difference in energy balance between the $\mathrm{H}-\mathrm{CC}$ and L-CC treatments. This energy difference, if entirely used for milk production, would account for a difference of $2.6 \mathrm{~kg}$ of ECM between H-CC and L-CC. The observed difference of $1.5 \mathrm{~kg}$ (Table 5) in ECM yield is an indication that part of the additional energy in L-CC could have been used for BW gain. The energy cost for detoxifying the absorbed ammonia generated by high RDP into urea could also be largely responsible for the decrease in milk yield, $\mathrm{MF}_{\text {protein, }}$, and $\mathrm{MF}_{\text {average }}$.

Most studies have not reported any differences in concentrations of milk components with different concentrations of dietary RDP (Casper et al., 1999; Dunlap et al., 2000). The quadratic response in protein concentration (Table 5) may be associated with variations in the AA quantities and profiles among treatments, but they were not tested in this experiment. However, because the MP decreased with increasing RDP, the milk protein yield decreased linearly (Table 3 ). Another explanation for the quadratic response in protein concentration could be the dilution effect caused by differences in osmotic responses from lactose production. Lactose yield was higher for L-CC than M-CC (Table 5). The difference between L-CC and M-CC ( $73 \mathrm{~g} / \mathrm{d}$ ) was greater than the difference between M-CC and H-CC (19 g/d). Although lactose plays an important role in osmotic responses (Larson, 1985), the difference in lactose was not significant in this experiment; however, the dilution of milk components may be more important for L-CC than M-CC, and the difference would be less than the difference between M-CC and $\mathrm{H}-\mathrm{CC}$.

\section{Effect of Corn Grinding with High RDP Levels}

The site of digestion is affected by grinding, with the ruminal degradability of carbohydrates being higher for ground corn than for cracked corn (Cerneau and Michalet-Doreau, 1991). Higher carbohydrate degradability and higher NFC with the H-GC treatment (Table 2 ) would increase the synchronization of energy and protein in the rumen in a diet high in RDP. In our postexperimental simulation with actual data from individual cows, the NRC (2001) model predicted increased estimated MP-bacterial with ground corn (Table 3). However, this estimated increase was moderate and the amount of absorbed ammonia would have been similar to that of the H-CC treatment. The higher milk yield (Table 5), higher $\mathrm{N}$ efficiency (Table 5), lower MUN (Table 5), and lower plasma urea-N (Table 6) of the $\mathrm{H}$ GC treatment, in comparison with the $\mathrm{H}-\mathrm{CC}$ treatment, indicate increased $\mathrm{N}$ utilization by rumen microorganisms. This result indicates that the NRC model may underestimate the impact of ground corn on bacterial MP when excess RDP is fed. The increase in microbial growth might have contributed to higher DMI for $\mathrm{H}$ GC than H-CC (Table 5) because fiber digestion by microorganisms might also have increased (Hino and Hamano, 1993). In addition, H-GC had a lower NDF content (Table 2) than, but an NDF intake similar to (Table 3 ), H-CC and the NDF content is known to have an impact on DMI (Mertens, 1994). The impact of corn grinding on DMI is not clear. Ekinci and Broderick (1997) reported an increase in DMI with the processing of high-moisture ear corn, and corn grinding has been shown to increase DMI when combined with alfalfa silage (Charbonneau et al., 2006), but most studies have not reported higher DMI with corn grinding (Knowlton et al., 1996; Wilkerson et al., 1997; Dhiman et al., 2002).

Compared with the H-CC treatment, the H-GC treatment had a higher DMI (Table 3), with a tendency to increase the estimated $\mathrm{NE}_{\mathrm{L}}$ supplied (Table 3), and had a better utilization of $\mathrm{N}$ in the rumen, as discussed previously. As a result, animals receiving the H-GC treatment would likely have had better AA availability, and this could explain the higher values for milk yield, protein-corrected milk, milk protein yield, lactose yield, protein concentration (Table 5), plasma glucose (Table 6 ), and $\mathrm{MF}_{\text {protein }}$ (Table 7). The higher milk yields of the H-GC treatment (Table 5) corroborate earlier studies that document a link between corn processing and increased milk yield (Knowlton et al., 1996; Wilkerson et al., 1997; Dhiman et al., 2002). Lower fat and higher protein contents in milk with ground corn (Table 5) have also been documented (Knowlton et al., 1996; Dhiman et al., 2002), although some studies have obtained lower contents of both fat and protein (Mitzner et al., 1994) or no significant change for fat but a higher protein content (Moe et al., 1973; Wilkerson et al., 1997). The lack of difference in fat yield (Table 5) may be due to the fat being diluted with increased milk yield.

\section{Forage Utilization}

The results from this study indicate the importance of concentrate choice on MF. Allowable MF (Charbonneau et al., 2006), as in the Milk 2000 model (Schwab et al., 2003), evaluates the capacity for milk production by forages and is a good tool to evaluate the capacity of a farm forage for milk production. In contrast to the latter 2 concepts, the calculation of MF is based on the 
whole diet. The calculations of MF assume that the energy and protein supplied by forages and concentrates are additive and that concentrates are fully used by the cow for milk yield; only the proportion of milk that could not theoretically be produced by the concentrates is attributed to forage (Charbonneau et al., 2006). Because this equation considers the concentration of nutrients in concentrates, it can be used to indicate feed efficiency as well as good forage utilization. The differences between AMF and MF (Table 7) indicate that the forages were not used to their full potential. Low MF and differences between AMF and MF (Table 7) are the result of excessive concentrates in the diet. In this experiment, the treatments were high in concentrates because of a low estimate of DMI based on the NRC (2001) model. The decrease in $\mathrm{MF}_{\text {protein }}$ with the increasing RDP from concentrates indicates that there was already a good energy-to-RDP ratio with the low$\mathrm{RDP}$ concentrates. In addition, the increase in $\mathrm{MF}_{\text {protein }}$ with $\mathrm{H}-\mathrm{GC}$, in comparison with $\mathrm{H}-\mathrm{CC}$, confirms the importance of achieving a good combination of concentrates when using mixtures of alfalfa and corn silage. Because treatments with higher $\mathrm{MF}_{\text {protein }}$ also showed an increase in DMI, which increased the AMF, the increase in $\mathrm{MF}_{\text {protein }}$ did not result in a decrease difference between $\mathrm{AMF}_{\text {protein }}$ and $\mathrm{MF}_{\text {protein }}$.

\section{CONCLUSIONS}

The results of this study indicate that feeding RDP in excess of NRC recommendations reduces production and increases $\mathrm{N}$ excretion through reduced utilization of $\mathrm{N}$ for production. This confirms the importance of synchronizing rumen degradability of energy and protein sources from concentrates when corn and alfalfa silages are used together. When cracked corn is the energy source, it is not efficient to increase the RDP levels over NRC (2001) recommendations. Lower RDP levels improved $\mathrm{MF}_{\text {protein }}$ and milk yield. However, the negative impact of a high RDP level was counterbalanced by using ground corn as an efficient way to increase milk yield and $\mathrm{MF}_{\text {protein. }}$. This experiment confirms that effective combinations of concentrates can increase $\mathrm{MF}_{\text {protein }}$.

\section{ACKNOWLEDGMENTS}

The authors thank Annie Brégard for her help during the experiment. Sincere appreciation is also extended to the Centre de recherche en sciences animales de Deschambault, where the experiment took place, and to its staff. Thanks go to Francine Giguère, André Roy, Micheline Gingras, and Jean Bricault of the Département des Sciences Animales, Université Laval, and to
Mario Léonard from Agriculture and Agri-Food Canada, Lennoxville, for laboratory assistance. Appreciation is also extended to Rachel Gervais and Nicolas StPierre, graduate students at Université Laval, for their help during sample collection. This study was supported by a grant from the Action concertée FCARNovalait-MAPAQ. The research scholarship awarded to Edith Charbonneau from Le Fonds québécois de la recherche sur la nature et les technologies is also gratefully acknowledged.

\section{REFERENCES}

Aldrich, J. M., L. D. Muller, G. A. Varga, and L. C. Griel, Jr. 1993. Nonstructural carbohydrate and protein effects on rumen fermentation, nutrient flow, and performance of dairy cows. J. Dairy Sci. 76:1091-1105.

Ankom Technology. 1999a. Method for determining acid detergent fiber. Technical report. Ankom Technology, Macedon, NY.

Ankom Technology. 1999b. Method for determining neutral detergent fiber. Technical report. Ankom Technology, Macedon, NY.

AOAC. 1990. Official Methods of Analysis. 15th ed. AOAC, Arlington, VA.

Canadian Council on Animal Care (CCAC). 1993. Guide to the Care and Use of Experimental Animals. Vol. 1. 2nd ed. CCAC, Ottawa, Ontario, Canada.

Casper, D. P., H. A. Maïga, M. J. Brouk, and D. J. Schingoethe. 1999. Synchronization of carbohydrate and protein sources on fermentation and passage rates in dairy cows. J. Dairy Sci. 82:1779-1790.

Casper, D. P., D. J. Schingoethe, and W. A. Eisenbeisz. 1990. Response of early lactation dairy cows fed diets varying in source of carbohydrate and crude protein. J. Dairy Sci. 73:1039-1050.

Cerneau, P., and B. Michalet-Doreau. 1991. In situ starch degradation of different feeds in the rumen. Reprod. Nutr. Dev. 31:65-72.

Charbonneau, E., A. Brégard, G. Allard, D. Lefebvre, and D. Pellerin. 2003. Revisiting the prediction of milk from forage according to NRC 2001. Can. Soc. Anim. Sci. Ann. Mtg., June 11-13, Saskatoon, Saskatchewan. (Abstr.)

Charbonneau, E., P. Y. Chouinard, G. Allard, H. Lapierre, and D. Pellerin. 2006. Milk from forage as affected by carbohydrate source and degradability with alfalfa silage-based diets. J. Dairy Sci. 89:283-293.

Dhiman, T. R., and L. D. Satter. 1997. Yield response of dairy cows fed different proportions of alfalfa silage and corn silage. J. Dairy Sci. 80:2069-2082.

Dhiman, T. R., M. S. Zaman, I. S. MacQueen, and R. L. Boman. 2002. Influence of corn processing and frequency of feeding on cow performance. J. Dairy Sci. 85:217-226.

Dunlap, T. F., R. A. Kohn, L. W. Douglass, and R. A. Erdman. 2000. Diets deficient in rumen undegraded protein did not depress milk production. J. Dairy Sci. 83:1806-1812.

Ekinci, C., and G. A. Broderick. 1997. Effect of grinding high moisture ear corn on ruminal fermentation and milk yield. J. Dairy Sci. 80:3298-3307.

Garcia-Bojalil, C. M., C. R. Staples, C. A. Risco, J. D. Savio, and W. W. Thatcher. 1998. Protein degradability and calcium salts of long-chain fatty acids in the diets of lactating dairy cows: Productive responses. J. Dairy Sci. 81:1374-1384.

Hino, T., and S. Hamano. 1993. Effect of readily available carbohydrates on fiber digestion by rumen microbes in continuous culture. Anim. Feed Sci. Technol. 64:1070-1078.

Huntington, G. B. 1984. Net absorption of glucose and nitrogenous compounds by lactating Holstein cows. J. Dairy Sci. 67:19191927.

Knowlton, K. F., M. S. Allen, and P. S. Erickson. 1996. Lasalocid and particle size of corn grain for dairy cows in early lactation. 1 . Effect 
on performance, serum metabolites, and nutrient digestibility. J. Dairy Sci. 79:557-564.

Larson, B. L. 1985. Biosynthesis and cellular secretion of milk. Pages 129-163 in Lactation. Iowa State University Press, Ames.

Martin, A. K., and K. L. Blaxter. 1965. The energy cost of urea synthesis in sheep. Pages 83-91 in Energy Metabolism. K. L. Blaxter, ed. Academic Press, New York, NY.

McCutcheon, S. N., and D. E. Bauman. 1986. Effect of chronic growth hormone treatment on response to epinephrine and thyrotropinreleasing hormones in lactating cows. J. Dairy Sci. 69:44-51.

Mertens, D. R. 1994. Regulation of forage intake. Pages 450-493 in Forage Quality, Evaluation and Utilization. G. C. Fahey, ed. Am. Soc. Agron., Crop Sci. Soc. Amer., Soil Sci. Soc. Am., Madison, WI.

Mitzner, K. C., F. G. Owen, and R. J. Grant. 1994. Comparison of sorghum and corn grains in early and midlactation diets for dairy cows. J. Dairy Sci. 77:1044-1051.

Moe, P. W., H. F. Tyrell, and N. W. Hooven, Jr. 1973. Physical form and energy value of corn grain. J. Dairy Sci. 56:1298-1304.

NRC. 2001. Nutrient Requirements of Dairy Cattle. 7th rev. ed. Natl. Acad. Press, Washington, DC.
Oldham, J. D. 1984. Protein-energy interrelationship in dairy cows. J. Dairy Sci. 67:1091-1114.

Santos, F. A. P., J. E. P. Santos, C. B. Theurer, and J. T. Huber. 1998. Effects of rumen-undegradable protein on dairy cow performance: A 12-year literature review. J. Dairy Sci. 81:3182-3213.

SAS Institute. 2001. SAS System Software: Release 8.2 (TS2MO). SAS Inst., Inc., Cary, NC.

Shabi, Z., A. Ariele, I. Bruckental, Y. Aharoni, S. Zamwel, A. Bor, and $H$. Tagari. 1998. Effect of the synchronization of dietary crude protein and organic matter and feeding frequency on ruminal fermentation and flow of digesta in the abomasum of dairy cows. J. Dairy Sci. 81:1991-2000.

Schwab, E. C., R. D. Shaver, J. G. Lauer, and J. G. Coors. 2003. Estimating silage energy value and milk yield to rank corn hybrids. Anim. Feed Sci. Technol. 109:1-18.

Wilkerson, V. A., B. P. Glenn, and K. R. McLeod. 1997. Energy and nitrogen balance in lactating cows fed diets containing dry or high moisture corn in either rolled or ground form. J. Dairy Sci. 80:2487-2496. 